\title{
The Effect of Simulation-based Training on the Self- confidence and Self-satisfaction of Nursing Students Dealing with Patients under Isolation
}

\section{Temas İzolasyonlu Hastada Simülasyona Dayalı Eğitimin Hemşirelik Öğrencilerinin Özgüven ve Memnuniyetine Etkisi}

(i) Çağla KARATAŞ1, id Hilal TÜZER²

1Ankara University Faculty of Medicine, Division of Nursing, Ankara, Turkey

${ }^{2}$ Ankara Yıldırım Beyazıt University Faculty of Health Sciences, Division of Nursing, Ankara, Turkey

\section{ABSTRACT}

Objective: Simulation is an innovative education model that is highly effective in nursing training. The implementation of innovative training programmes on the importance of infection control increases the awareness of nursing students and ensures less anxiety when providing care to patients under isolation.

Methods: The study was conducted on 30 second-year students at a university nursing school. The students first gave a pretest and their initial performance was evaluated through a low-fidelity simulator. This was followed by a theoretical training. Every student in the study group worked with a standardised patient based on an appropriate scenario regarding the care of the patient under contact isolation. Debriefing sessions were then conducted in groups of five students. Following the application, the students were tested on the satisfaction and self-confidence scales through a post-test.

Results: The post-test scores were significantly higher than the pretest scores $(p<0.05)$. A significant relationship was found between the self-confidence and satisfaction scores of the students $(\mathrm{p}<0.05, \mathrm{r}=0.538)$.

Conclusion: The training provided through a standardised patient was found to contribute to the knowledge scores of the students regarding the care of a patient under contact isolation.

Keywords: Simulation, contact isolation, nursing training, standardised patient

\section{ÖZ}

Amaç: Yenilikçi bir eğitim modeli olan simülasyon hemşirelik eğitiminde oldukça etkilidir. Enfeksiyon kontrolünün önemi ile ilgili yenilikçi eğitim programlarının uygulanması, hemşirelik öğrencilerin konuyla ilgili farkındalığını artırmakta ve izole hastaların bakımı sırasında öğrencilerin kaygı düzeyinin azalmasını sağlamaktadır.

Yöntemler: Araştırmanın örneklemini, bir üniversitenin hemşirelik bölümünde 2. sınıfta öğrenim gören 30 öğrenci oluşturmuştur. Çalışmada öğrencilere öncelikle ön test uygulanmış ve ilk performansları düşük gerçeklikli simülatör ile değerlendirilmiş daha sonra teorik eğitim verilmiş̧ir. Araştırmaya katılan her öğrenci senaryo eşliğinde standart hastayla çalışmıştır. Çözümleme görüşmeleri 5 öğrenciden oluşan gruplar şeklinde yürütülmüştür. Uygulama sonrasında öğrenciler öğrenmede memnuniyet ve özgüven ölçeğini uygulamış ve son test yapmışlardır.

Bulgular: Araştırmadan elde edilen sonuçlara göre öğrencilerin bilgi puanları incelendiğinde son test puanlarının ön test puanlarından anlamlı derecede yüksek olduğu bulunmuştur $(\mathrm{p}<0,05)$. Çalışmaya katılan öğrencilerin özgüven ve memnuniyet puanları arasında anlamlı bir ilişki görülmektedir ( $\mathrm{p}<0,05, \mathrm{r}=0,538)$.

Sonuç: Araştırma sonuçlarına göre; hemşirelik öğrencilerine temas izolasyonlu hasta bakımına yönelik standart hasta kullanılarak verilen eğitimin öğrencilerin bilgi puanlarının katkı sağladığı görülmüştür.

Anahtar Sözcükler: Simülasyon, temas izolasyonu, hemşirelik eğitimi, standart hasta

Address for Correspondence: Hilal TÜZER, Ankara Yıldırım Beyazıt University Faculty of Health Science,

E-mail: htuzer@ybu.edu.tr ORCID ID: orcid.org/0000-0002-9929-3688

Cite this article as: Karataş Ç, Tüzer $\mathrm{H}$. The Effect of Simulation-based Training on the Self-confidence and Self-satisfaction of Nursing Students Dealing with Patients under Isolation. Bezmialem Science 2020;8(3):227-32. 


\section{Introduction}

Advances in science and technology is growing continuously, changing and influencing all industries, healthcare being one of them. They also affect directly or indirectly the nursing care provided to the patient $(1,2)$. Nursing students new to clinical practice are affected negatively from factors such as the complex technological environment, inexperience, fear of making mistakes, stress and the negative attitudes of the staff $(3,4)$. When performing certain procedures for the first time, the students are extremely intimidated and anxious about making a mistake or harming the patient. They are also concerned about their limitations as to learn or perform adequately due to insufficient practice and supervision (5). In addition, nursing training is currently facing many difficulties such as decreased teaching staff and an increased number of students, requiring trainers to consider innovative strategies (6).

Nursing education and modern healthcare are both changing rapidly. Simulation has become an innovative and effective educational model. It has been used in many countries for the last 20 years, however, in our country, it has been started to be used only recently. Simulation is used to create realistic environments for training. According to the definition of Gaba (7), "Simulation is a technique-not a technology-to replace or amplify real experiences with guided experiences that evoke or replicate substantial aspects of the real world in a fully interactive manner".

Learning in simulation-based training takes place in a risk-free environment, where the student is allowed to make mistakes. This enables training and care to be provided while ensuring patient safety and without violating patient rights. The technique allows students to learn from their mistakes because these mistakes are allowed to reach their natural consequences, unlike in clinical practice where this would not be ethical $(8,9)$.

The use of a standardized patient is one of the most effective simulation approaches in nursing training. It has been shown to be very effective in increasing the knowledge, performance, self-confidence and satisfaction of students in many studies (1012). A randomised controlled study conducted by the National Council of State Boards of Nursing in USA nursing schools has reported the simulation environment to be as realistic as the hospital environment. It was also found to be risk-free in terms of student and patient safety (13).

Hospital infections or "Healthcare Acquired Infections" constitute a threat to the safety of both the patients and healthcare employees. They are among the most important health problems both in our country and globally (14). Anderson et al. (14) have reported nurses being afraid when providing care to patients infected with Methicillin-Resistant Staphylococcus aureus (MRSA). However, these nurses were able to provide care more comfortably to such patients after receiving training on MRSA control and prevention (15). The use of a standardized patient for infection control training enables students to use appropriate infection control methods such as correct hand hygiene practice (9).
Increasing the awareness of students on infection control and decreasing their anxiety requires preparing relevant training programmes on how microorganisms cause infection and how these can be prevented (15).

Students report that isolation procedures create specific physical and psychological patient requirements. They also affect the care provided to the patient and the relationship between the patient and the nurse. Assigning students to departments related to infection or giving them responsibility for the care of patients under isolation accelerates learning. The mechanism is believed to be forcing them to use their theoretical knowledge in clinical practice and reinforcing the trust relationship between the patient and the nurse. Patients under isolation have been found to be visited less often; the nurses also have less contact with the patient $(15,16)$. It is important for infection control purposes for nurses to have good knowledge of infection control and prevention methods, personal protective equipment use and hand hygiene $(13,17)$.

Simulation is an innovative education model that is highly effective in nursing training. The implementation of innovative training programmes on the importance of infection control increases the awareness of nursing students and ensures less anxiety when providing care to patients under isolation.

\section{Methods}

\section{The Form of the Study}

The aim of this semi-experimental study was to investigate the effect of training using a standardized patient on the selfconfidence and satisfaction of the students when caring for a patient under contact isolation.

\section{The Population and Sample of the Study}

The study was conducted on the university nursing students taking the "Surgical Diseases Nursing" course during the spring semester of the 2016-2017 academic year. A total of 125 students were taking this course.

The study sample size was determined as 40 students. The number was originally calculated as 28 students according to the study universe $(\mathrm{n}=125)$ and the no-response rate was then taken into account. The study was finally conducted on 30 students who volunteered and accepted to participate.

\section{Data Collection Forms}

Data collection forms such as the "Pretest/Post-test for Measuring the Level of Knowledge on Contact Isolation", "Student Evaluation Guidelines in the Care of the Patient under Contact Isolation", "Debriefing Form" and "Student Satisfaction and Self-confidence Scale in Learning" based on literature study were prepared by the researchers and used to collect data.

Corrections were made for content validity according to the recommendations of three experts on the subject (two nursing teaching staff and a physician). The data collection tools used for the measurement were evaluated by a measurement and evaluation specialist. 
Contact Isolation Knowledge Test: The "Pretest/Post-test for Measuring the Level of Knowledge on Contact Isolation" included 14 multiple-choice questions. The test was based on the literature, and it was used to measure the level of knowledge of the nursing students regarding contact isolation.

Student Evaluation Guidelines in the Care of the Patient under Contact Isolation: These guideless consisted of 21 items, also taken from the literature. The aim was to determine whether the student had performed the steps appropriately. Scoring options were "Observed Correct/Complete", "Observed Incomplete/Incorrect" and "Not Observed" with a score of 2, 1 and 0 , respectively.

\section{Student Satisfaction and Self-confidence Scale in Learning:} This scale was prepared by the National League for Nursing and the validity and reliability study for Turkey was conducted by Unver et al. (18). The original scale was developed by Jeffries and Rizzolo (19) and included 13 items, which was reduced to 12 during the adaptation to Turkish. The scale used was a 5-item Likert type (1: I definitely do not agree, 2: I do not agree, 3: I am undecided, 4: I agree, 5: I definitely agree). It also included the "Satisfaction with Present Learning" and "Self-confidence in Learning" subtopics, consisting of five and seven items, respectively. There were no negative items. The total of the subdimension scores did not give the total score in this scale. The scale scores were obtained by dividing the total sub-dimension scores by the number of items. An increased total scale score indicated increased student satisfaction and self-confidence.

Debriefing Form: This form was created to receive feedback from the students. It was also used to evaluate the student after the practical session with a standardised patient. The form consisted of open-ended queries on issues such as "how the student felt" and "what they could do differently after the practice".

\section{Implementation of the Research}

The students included in the study first gave a pretest. The aim was to evaluate their knowledge on the care of a patient under contact isolation. The initial performance of each student was evaluated using a low-fidelity simulator. This evaluation was conducted at the Nursing Department Skill laboratory by the investigator using the student evaluation guidelines. The students were then given a theoretical training on both the verbal methods and the demonstration regarding their approach to the patient under contact isolation.

Each student practiced at the simulation laboratory with the standardised patient. An appropriate scenario regarding the care of the patient under contact isolation was used. The students were observed by the investigator during the practice and their performances were then evaluated according to the student evaluation guidelines. Also, a video recording of this practice session was made.

Debriefing sessions were then conducted in groups of five students. During this session, the students watched their video recordings and their corresponding responses during the session were recorded as audio files. They were given feedbacks on their performance by the investigator and other students. At the end of the study, all students evaluated their satisfaction and selfconfidence rate. The Student Satisfaction and Self-confidence Scale on Learning was used for this purpose. Finally, the level of knowledge was determined with the post-test (Figure 1).

\section{Ethical Dimension of the Study}

This study was approved by the university Ethics Committee on 22 February 2017 (Decision no: 10). A written permission, dated 9 January 2017 (Number: $78033166 / 15$ ), was also obtained from the head of the Nursing Department. All participants signed an informed consent form prior to the study.

\section{Study Limitations}

The lack of a control group in our study and the small number of students are among our limitations. The inability to observe student performance with an actual hospital patient can also be considered a limitation.

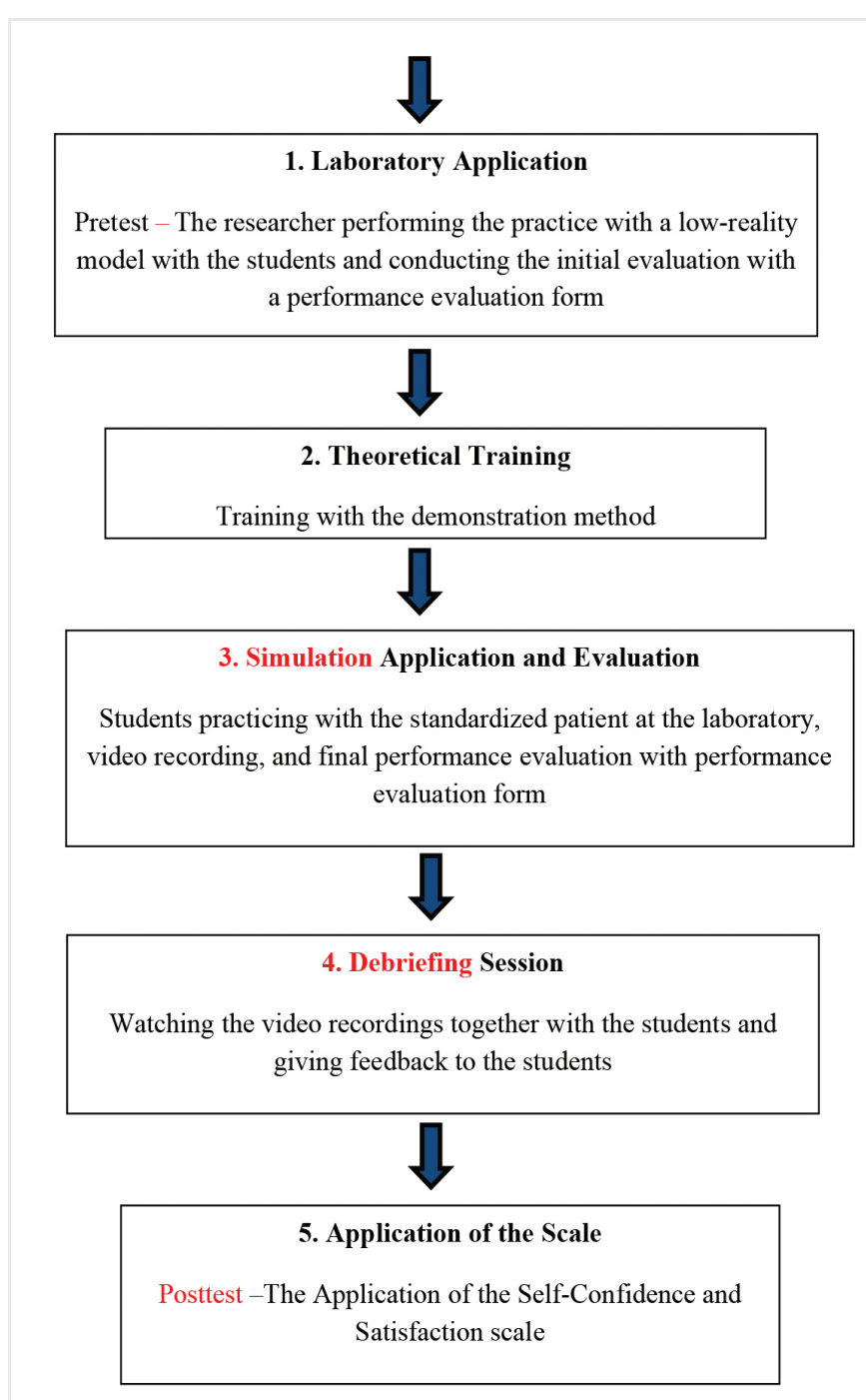

Figure 1. Application flow chart of the study 


\section{Evaluation of the Data}

Data were analysed using the IBM SPSS Statistics software program, version 22. The Shapiro-Wilk test was used to evaluate whether the variables had a normal distribution. The number and percentage values were presented for frequency distributions. The mean, standard deviation and other descriptive statistics were used for the distribution of the scores. The Pearson's Correlation Coefficient was used to evaluate the correlation between normally distributed variables. The variables were normally distributed, and the paired sample $t$-test was used to evaluate the difference between two dependent variables. A p value of 0.05 was accepted as the significance level when interpreting the results. Values of $95 \%$ confidence, $84 \%$ theoretical power and 0.5 effect size were used for power analysis. At least 30 subjects were planned to be studied.

The questions used in the analysis were prepared in a semistructured interview form. The views of the students were presented without performing content analysis.

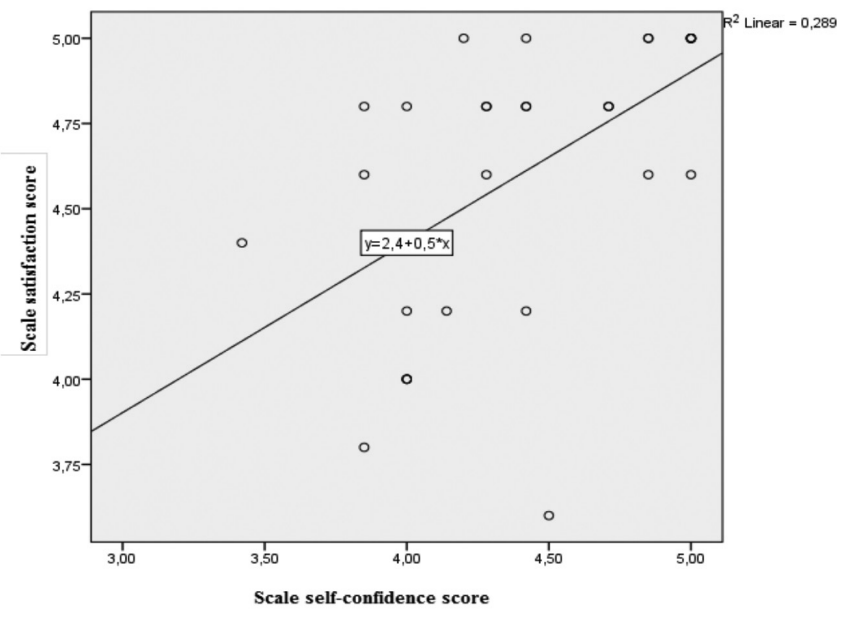

Figure 2. Relationship between self-satisfaction and selfconfidence

\section{Results}

Females and males made up $86.7 \%(n=26)$ and $13.3 \%(n=4)$ of our student population, respectively.

The mean contact isolation pretest knowledge score was $65.05 \pm 14.13$. The mean post-test knowledge score was $87.83 \pm 9.41$. The post-test scores were significantly higher than the pretest scores $(\mathrm{p}<0.05)($ Table 1$)$.

The mean contact isolation pretest knowledge score was $65.05 \pm 14.13$. The mean post-test knowledge score was $87.83 \pm 9.41$. The post-test scores were significantly higher than the pretest scores $(\mathrm{p}<0.05)($ Table 1$)$.

The mean performance score of the students before the training was $59.54 \pm 12.06$ with the low-reality simulator. The score was $74.69 \pm 8.39$ during the practice with the standardised patient. The performance scores showed a significant increase after the training $(\mathrm{p}<0.05)$ (Table 2).

A significant relationship was found between the Self-confidence and Satisfaction scores $(\mathrm{p}<0.05, \mathrm{r}=0.538)$ (Figure 2). The satisfaction scores of the students increased with their selfconfidence scores. A significant relationship was also present between the increase in the self-confidence scores and the knowledge scores $(\mathrm{p}<0.05, \mathrm{r}=0.373)$; the self-confidence score increased as the knowledge score increased.

\section{Students' Views}

During the debriefing session, the students stated that they had noticed their mistakes while working with the standardised patient. They felt that the practice had raised their awareness and self-confidence and self-satisfaction. They also felt they could now provide care to the patient under contact isolation more comfortably and with increased courage during clinical practice:

"They are not paying attention to these at the hospital. I realized what I needed to do to for approaching patients under contact isolation after this practice".

"Watching myself on the video made me better realize the mistakes I had made".

Table 1. Student Contact Isolation Knowledge Test score distributions

\begin{tabular}{|l|l|l|l|l|l|l|l|l|l|}
\hline Contact Isolation Knowledge score & $\mathrm{n}$ & Mean & Median & Minimum & Maximum & SD & p value \\
\hline Pretest score & 30 & 65.05 & 64.27 & 35.70 & 85.71 & 14.13 & -8.1 & 0.0001 \\
\hline Post-test score & 30 & 87.83 & 85.68 & 64.26 & 100.00 & 9.41 &
\end{tabular}

SD: Standard deviaiton

Table 2. Student Performance Score Distribution for the care of the patient under contact isolation

\begin{tabular}{|c|c|c|c|c|c|c|c|c|}
\hline & $n$ & Mean & Median & Minimum & Maximum & SD & t & $p$ value \\
\hline $\begin{array}{l}\text { Low-reality } \\
\text { simulator }\end{array}$ & 30 & & & & & & -6.01 & 0.0001 \\
\hline
\end{tabular}


"I noticed that I needed better knowledge to provide better training for the patient".

"I was afraid to approach this kind of patient but I can now provide care more comfortably".

\section{Discussion}

It was found that training using a standardized patient on the care of patients under contact isolation resulted in a significant increase in the knowledge scores of the students $(\mathrm{p}<0.05)$.

Crowe et al. (20) in their study also reported a significant increase in the knowledge scores of the students after a simulation-based training. The use of standardised patients in training has been reported to provide an ease of learning to the nursing students. It was also found to have a positive effect on their knowledge and performance in the clinical environment, similar to our study $(10,21)$. Shin et al. (22) have reported simulation-based training to be more effective than traditional training in their 2015 article with a meta-debriefing on simulation practices for nursing students. Simulation training enables one-on-one learning in an interactive environment. This kind of environment is studentcentred, with the educator merely acting as a guide to the student.

A significant relationship was found between the self-confidence and knowledge scores before and after the training with a standardized patient with respect to providing care to the patient under contact isolation $(\mathrm{p}<0.05, \mathrm{r}=0.373)$. The self-confidence scores increased as the satisfaction scores increased.

The students reported being satisfied with the training using a standardized patient and an increased self-confidence while learning the content. Zulkosky (23) has also reported increased student satisfaction in a similar study. Our study revealed that student satisfaction increased as the self-confidence increased.

Moura et al. (24) investigated the effect of simulation on the development of clinical skills for the evaluation of the pressure ulcer risk. They found a significant increase in the critical thinking, self-confidence and skill scores of nurses after the training (24). Simulation training has been reported to increase the self-confidence and self-satisfaction of students in other studies as well (25-27).

In a study conducted by Basak et al. (28) in 2018, with the aim to develop the hygienic care skills of first-grade nursing students, the satisfaction and self-confidence scores of the students in the standardized patient group were found to be significantly higher than the students in the simulator group.

A student is generally a passive listener in the classical training method but participates actively during training with a standardised patient. This gives them a more active role in the training process together with increased performance and selfconfidence. Traditional training is usually teacher-centred and learning is only superficial. The simulation method enables students to learn from their mistakes, thus allowing them to observe the natural consequences of their mistakes, contrary to the clinical practice.
An important point of our study was the feedback of the students after the debriefing session. The debriefing session is one of the main building blocks of simulation-based training (29). Using debriefing sessions in simulation training has been reported to help systematic learning with the students experiencing less anxiety afterwards $(30,31)$.

\section{Conclusion}

Our results indicate that training nursing students with a standardized patient makes a positive contribution to the knowledge scores, self-confidence and satisfaction of the students on providing care to patients under contact isolation. We recommend enabling nursing students to practice with a standardized patient before clinical training and integrating simulation training to the curriculum in all nursing schools. Similar future studies on larger student groups and using a control group could also help reinforce our conclusions.

\section{Ethics}

Ethics Committee Approval: This study was approved by the university Ethics Committee on 22 February 2017 (Decision no: $10)$.

Informed Consent: All participants signed an informed consent form prior to the study.

Peer-review: Internally peer reviewed.

\section{Authorship Contributions}

Concept: Ç.K., H.T., Design: Ç.K., H.T., Data Collection or Processing: Ç.K., Analysis or Interpretation: Ç.K., H.T., Literature Search: Ç.K., Writing: Ç.K.

Conflict of Interest: No conflict of interest was declared by the authors.

Financial Disclosure: The authors declared that this study received no financial support.

\section{References}

1. Krau SD. The influence of technology in nursing education. Nurs Clin North Am 2015;50:379-87.

2. Lee LYK, Lee JKL, Wong KF, Tsang AYK, Li MK. The establishment of an integrated skills centre for undergraduate nursing education. Int Nurs Rev 2010;57:359-64.

3. Moscaritolo LM. Interventional strategies to decrease nursing student anxiety in clinical learning environment. J Nurs Educ 2009;48:1723.

4. Debourgh GA, Prion SK. Using simulation to teach prelicensure nursing students to minimize patient risk and harm. Clin Simul Nurs 2011;7:47-56.

5. Hanson CM, Hamric AB. Reflections on the continuing evolution of advanced practice nursing. Nurse Outlook 2003;51:203-11.

6. Lasater K. High-fidelity simulation and the development of clinical judgment: students' experiences. J Nurs Educ 2007;46:269-75. 
7. Gaba DM. The future vision of simulation in healthcare. Simul Healthce 2007;2:126-35.

8. Flude LM, Rosseel DH, Hiscock CJ, Pulling C, Gauthier J, Knapp A, et al. Interprofessional infection control education nursing standardized patients for nursing, medical and physiotherapy students. Journal of Interprofessional Education \& Practice 2016;2:25-31.

9. Bridgen D, Dangerfield P. The role of simulation in medical education. Clin Teach 2008;5:167-70.

10. Tuzer H, Dinc L, Elcin M. The effects of using high-fidelity simulators and standardized patients on the thorax, lung, and cardiac examination skills of undergraduate nursing students. Nurse Educ Today 2016;45:120-5.

11. Sarikoc G, Ozcan TC, Elcin M. The impact of using standardized patients in psychiatric cases on the levels of motivation and perceived learning of the nursing students. Nurse Educ Today 2017;51:15-22.

12. Andrea J, Kotowski Peggy. Using standardized patients in an undergraduate nursing health assessment class. Clin Simul Nurs 2017;13:309-13.

13. Yokoe DS, Anderson DJ, Berenholtz SM, Calfee DP, Dubberke $\mathrm{ER}$, Ellingson $\mathrm{KD}$, et al. A compendium of strategies to prevent healthcare-associated infections in acute care hospitals: 2014 Updates. Am J Infect Control 2014;42:820-8.

14. Andersson H, Andreassen Gleissman S, Lindholm C, Fossum B. Experiences of nursing staff caring for patients with methicillinresistant Staphylococcus aureus. Int Nurs Rev 2016;63:233-41.

15. Dehkordi ML, Tavakol K. Experiences of nursing students in caring of patients in source isolation. Iran J Nurs Midwifery Res 2010;16:13-9.

16. Evans HL, Shaffer MM, Hughes MG, Smith RL, Chong TW, Raymond DP, et al. Contact Isolation in Surgical Patients: A barrier to care? Surgery 2008;134:180-8.

17. Brosio F, Kuhdari P, Stefanati A, Sulcaj N, Lupi S, Guidi E, et al. Knowledge and behaviour of nursing students on the prevention of healthcare associated infections. J Prev Med Hyg 2017;58:99-104.

18. Unver V, Basak T, Watts P, Gaiosa PV, Moss J, Tastan S, et al. The reliability and validity of the questionnaires: student satisfaction and self-confidence in learning, simulation design scale and educational practices questionnaire. 3rd International Conference on Healthcare and Life-Science Research; 2015 June 12-13; Singapore. doi.org/10. 1080/10376178.2017.1282319.
19. Jeffries PR, Rizzolo MA. Designing and implementing models for the innovative use of using simulation to teach nursing care of ill adults and children: A national, multi-site, multi-method study. New York, NY: National League for Nursing; 2006.

20. Crowe S, Ewart L, Derman S. The impact of simulation based education on nursing confidence, knowledge and patient outcomes on general medicine units. Nurse Educ Pract 2018;29:70-5.

21. Sarmasoglu S, Dinç L, Elçin M. Using Standardized Patients in Nursing Education: Effects on Students' Psychomotor Skill Development. Nurse Educ 2016;41:1-5.

22. Shin S, Park JH, Kim JH. Effectiveness of patient simulation in nursing education: meta-analysis. Nurse Educ Today 2015;35:176-82.

23. Zulkosky KD. Simulation use in the classroom: impact on knowledge acquisition, satisfaction and self-confidence. Clin Simul Nurs 2012;8:25-33.

24. Moura ECC, Caliri MHL. Simulation for the development of clinical competence in risk assessment for pressure ulcer. Acta Paul Enferm 2013;26:369-75.

25. Lashinger S, Medves J, Pulling C, McGraw R, Waytuck B, Harrison $\mathrm{MB}$, et al. Effectiveness of simulation on health profession students' knowledge, skills, confidence and satisfaction. Int J Evid Based Healthc 2008;6:278-302.

26. Lundberg KM. Promoting self-confidence in clinical nursing students. Nurse Educ 2008;33:86-9.

27. Bremner MN, Aduddell K, Bennett DN, VanGeest JB. The use of human patient simulators: best practices with novice nursing students. Nurse Educ 2011;31:170-4.

28. Basak T, Aciksoz S, Unver V, Aslan O. Using standardized patients to improve the hygiene care skills of first-year nursing students: a randomized controlled trial. Collegian 2018;1-6.

29. Rall M, Manser T, Howard ST. Key Elements of Debriefing for Simulator Training. Eur J Anaesthesiol 2000;17:8:516-7.

30. Ali AA, Musallam E. Debriefing quality evaluation in nursing simulation-based education: an integrative review. Clin Simul Nurs 2018;16:15-24.

31. Evain JN, Zoric L, Mattatia L, Picard O, Ripart J, Cuvillon P. Residual Anxiety After High Fidelity Simulation in Anaesthesiology: An Observational, Prospective, Pilot Study. Anaesth Crit Care Pain Med 2017;36:205-12. 